\title{
DINAMIKA GERAKAN LINGKUNGAN DAN GLOBAL ENVIRONMENTAL GOVERNANCE
}

\author{
Yety Rochwulaningsih
}

\author{
Magister Ilmu Sejarah Fakultas Ilmu Budaya \\ Universitas Diponegoro
}

Alamat korespondensi:wulan@undip.ac.id

Diterima/ Received: 10 Oktober 2017; Disetujui/ Accepted:31 Oktober 2017

\begin{abstract}
Through critical historical method with political ecological approach, this paper examines the occurrence of landslide that pose a serious threat to people's lives. Landslide intensity become higher and more prevalent in various regions in Indonesia. It is also become inseparable from the government's political economic policy in exploiting natural resources and massive penetration of global capitalist economic system which is very expansive and exploitative. The empirical facts on the implementation of Law No.5 / 1967, Law No. 11/1967, Law No. 5/1990 and TAP MPR No $I X / 2001$, indicates the entrance for utilization of natural resources beyond carrying capacity impacts on ecosystem damage and natural disaster which later become serious threat of people's life.
\end{abstract}

Keywords: Political Ecology; Ecosystem Damages; Landslide; Capitalistic Economy.

\begin{abstract}
Abstrak
Melalui metode sejarah kritis dengan pendekatan politik ekologi, tulisan ini mengkaji peristiwa bencana alam tanah longsor yang menjadi ancaman serius terhadap kehidupan masyarakat. Intensitas bencana tanah longsor yang semakin tinggi dan merata di berbagai kawasan di Indonesia tidak terlepas dari kebijakan ekonomi politik pemerintah dalam memanfaatkan sumber daya alam dan masifnya penetrasi sistem ekonomi kapitalis global yang sangat ekspansif dan eksploitatif terhadap sumber daya alam. Fakta empirik implementasi UU No.5/1967, UU No. 11/1967, UU No. 5/1990, dan TAP MPR No IX/2001, justru menjadi pintu masuk bagi pemanfaatan sumber daya alam melebihi carrying capacity yang berdampak terhadap kerusakan ekosistem dan bencana alam yang menjadi ancaman serius kehidupan masyarakat.
\end{abstract}

Kata Kunci: Politik Ekologi; Kerusakan Ekosistem; Longsor; Ekonomi Kapitalis.

\section{PENDAHULUAN}

Bencana alam tanah longsor di Indonesia pada dekade terakhir trennya cenderung meningkat meskipun sempat terjadi penurunan, yaitu terjadi 2.278 peristiwa selama kurun waktu 2005-2014 dengan korban 1.815 orang tewas dan hilang dengan rincian pada 2005 tercatat 50 kejadian,
2006 tercatat 73 kejadian, meningkat 104 kejadian pada 2007, 112 kejadian 2008 dan pada tahuntahun berikutnya terus meningkat, yaitu 238 kejadian, 400 kejadian, kemudian sempat terjadi penurunan menjadi 329 kejadian pada 2011, 291 kejadian 2012, naik lagi menjadi 296 kejadian, dan 385 kejadian 2014 (http://www.liputan6.com, 15 Desember 2014). Ironisnya berbagai peristiwa 
tragis justru menjadi polemik diantara berbagai pihak yang diekspos baik di media cetak, elektronik maupun forum-forum resmi. Di satu pihak jajaran pemerintah cenderung memandang peristiwa itu merupakan murni bencara alam di luar kehendak dan kekuasaan manusia, di pihak lain khususnya dari pemerhati dan pencinta lingkungan memandang itu akibat ulah manusia yang telah merusak ekosistem secara tidak bertanggung jawab (Suara Merdeka, 11 Januari 2006: $6 \& 9$ ).

Terjadinya berbagai peristiwa bencana alam tersebut dalam perspektif politik ekologi dan historis merupakan persoalan kompleks yang tidak terjadi secara instan, tetapi menyangkut kebijakan politik nasional jauh sebelum terjadinya berbagai peristiwa bencana yang terjalin juga dengan kekuatan-kekuatan ekonomi global. Bencana alam di berbagai tempat dan waktu terjadi antara lain karena ketidaksetimbangan bahkan kerusakan ekosistem dan itu merupakan akibat dari pelaksanaan pembangunan yang berideologi pertumbuhan ekonomi (economic growth), lebih menekankan pada capaian target-target pertumbuhan ekonomi bagi pemenuhan kebutuhan sekarang tanpa memperhitungkan kebutuhan generasi yang akan datang (Langhelle, 1999: 129-149).

Fakta historis menunjukkan bahwa negaranegara berkembang secara gencar menggalakan revolusi hijau melalui intensifikasi pertanian yang didukung oleh penggunaan teknologi moderen dan skenario global ini terbukti berhasil meningkatkan produksi pertanian secara maksimal, tetapi juga terbukti memberi kontribusi bagi terjadinya degradasi lingkungan (Pingali, 1989). Selain itu, sumber-sumber daya alam lainnya seperti hutan dan tambang, dalam rangka pemenuhan kebutuhan bahkan ambisi manusia sekarang juga dieksplorasi dan dieksploitasi secara maksimal. Oleh karena itu, kerusakan ekosistem di berbagai tempat dan kawasan telah menjadi ancaman yang serius bagi kelangsungan kehidupan umat manusia.

Berkaitan dengan semakin meluasnya kerusakan ekologi global tersebut mendorong timbulnya gerakan-gerakan sosial lingkungan yang mulai merebak sejak 1970-an. Ancaman kerusakan paling serius terutama menimpa pada segmen yang paling lemah dalam penguasaan sumber daya ekonomi dan kekuasaan, yaitu pedesaan/lokal yang mencakup komunitas dan ekologinya. Dalam konteks ini, di Indonesia fenomenanya sangat menonjol terutama sejak periode Orde Baru. Pada periode tersebut terjadi perubahan yang dramatis dalam ekologi sebagai dampak dari modernisasi dan industrialisasi yang merupakan mesin-mesin yang menggerakkan beroperasinya sistem ekonomi kapitalis. Melalui berbagai produk hukum, pemerintah tampak lebih berpihak pada pemilik modal sebagaimana tercermin dalam UU No.5/1967 tentang Ketentuan-ketentuan Pokok Kehutanan dan UU No. 11/1967 tentang Ketentuan-ketentuan Pokok Pertambangan. Dengan berbagai kebijakan itu posisi masyarakat lokal semakin lemah dan semakin tidak berdaya dalam menghadapi kekuatan kekuasaan (pemerintah) dan pemodal (kapitalis asing maupun dalam negeri). Bahkan revolusi hijau yang dengan gencar dilaksanakan pemerintah Orde Baru sebagai bagian yang integral dari skenario global, tidak saja gagal mengentaskan kemiskinan mayoritas masyarakat pedesaan (Sajogyo, 1974), tetapi telah menghancurkan sistem pertanian yang berkelanjutan yang telah mentradisi dalam kehidupan masyarakat pedesaan. UU No. 5 Tahun 1990 tentang Konservasi Sumber Daya Alam dan Ekosistemnya dan pasca-Orde Baru, TAP MPR No IX/2001 tentang Pembaharuan Agraria dan Pengelolaan Sumber Daya Alam, juga tidak memberi harapan pada masyarakat lokal karena rendahnya sensitivitas penguasa terhadap persoalan dasar masyarakat lokal (Robinson, 1984).

Kondisi yang demikian memberi kontribusi signifikan bagi maraknya gerakan sosial lingkungan oleh masyarakat lokal yang seringkali tidak terlepas dari bekerjanya jaringan organisasi non pemerintah (ornop) seperti Lembaga Swadaya Masyarakat (LSM) baik di tingkat lokal, regional, nasional maupun internasional (Escobar, 1997). Kecenderungan interconection seperti ini 
juga terjadi pada gerakan-gerakan sosial lingkungan di Wilayah Selatan, meskipun secara prinsip terdapat perbedaan. Di negara-negara Selatan gerakan lingkungan akhir abad XX telah dapat masuk dalam agenda politik negara dan pemerintah (Dwivedi, 2001), sedangkan di Indonesia belum jelas keberpihakannya terutama dalam tataran implementasi. Persoalan lingkungan hidup ini dapat melibatkan berbagai pihak seperti pemerintah suatu negara, organisasi dunia seperti Perserikatan Bangsa-Bangsa (PBB), LSM, gerakan-gerakan lingkungan, ilmuwan, dan masyarakat (Forsyth, 2003).

Seiring dengan tingkat kesadaran masyarakat terhadap bahaya perusakan lingkungan hidup yang semakin membaik khususnya di negara-negara berkembang, maka praktik-praktik eksploitasi terhadap sumber daya alam (natural resources) yang mengancam kelestarian lingkungan hidup mulai mendapat perlawanan dari berbagai elemen masyarakat. Mereka tergabung dalam berbagai organisasi LSM yang melakukan berbagai aktivitas gerakan lingkungan, yaitu gerakan yang bertujuan untuk meningkatkan kesadaran masyarakat terhadap pelestarian lingkungan hidup dan bahaya yang diakibatkan oleh perusakan lingkungan. Bahkan mereka juga melakukan resistensi terhadap berbagai pihak baik pemerintah maupun swasta yang secara langsung maupun tidak langsung memberi kontribusi bagi terjadinya kerusakan lingkungan hidup. Satu hal yang menarik adalah bahwa organisasi dan gerakan lingkungan ini bukan semata-mata organisasi yang bersifat lokal, tetapi mereka sering kali memiliki jaringan yang bersifat nasional bahkan internasional. Fenomena penguatan sektor ketiga ini (civil society organization ( $\mathrm{CSO}$ )/ civil society association (CSA), LSM) merupakan kekuatan gerakan sosial baru yang menguat sejak dirasakan gejala deep distrust terhadap organisasi politik konvensional seperti negara, birokrasi dan lembaga perwakilan rakyat (Dharmawan, 2005).

Sifat jaringan berbagai gerakan lingkungan yang bersifat global memberikan dampak yang signifikan terhadap proses penguatan masyarakat madani (civil society). Hal ini dimungkinkan mengingat bahwa organisasi lingkungan pada daerah tertentu bukanlah sebagai organisasi yang berdiri sendiri tetapi memiliki link dan bahkan sering kali berasosiasi dengan organisasi lingkungan secara nasional dan bahkan internasional. Apalagi link itu diperkuat dengan semakin mudah dan praktisnya penggunaan alat komunikasi seperti telefon, faximile, email, teleconference, dan dunia media sosial sebagai kekuatan yang signifikan di luar pemerintah dalam penentuan kebijakan khususnya di bidang-bidang yang berhubungan dengan lingkungan hidup. Jaringan inilah yang sesungguhnya menjadi kekuatan tawar-menawar dengan pemerintah. Pemerintah tidak akan gegabah melakukan tindakan represif terhadap organisasi lingkungan yang ada, meskipun mereka mungkin melakukan resistensi terhadap kebijakan yang menimbulkan dampak destruktif terhadap lingkungan hidup. Dengan demikian pemerintah bukan merupakan kekuatan tunggal dalam mengambil setiap kebijakan yang berkaitan dengan eksistensi lingkungan hidup yang harmonis. Dalam hubungan itulah tulisan ini akan mengkaji permasalahan bagaimana dinamika gerakan lingkungan berlangsung dan kemampuannya dalam mendorong penguatan masyarakat madani dalam kerangka sebuah global environmental governance?

\section{METODE}

Melalui metode sejarah kritis dengan pendekatan politik ekologi, bencana alam tanah longsor yang semakin serius mengancam kehidupan masyarakat Indonesia dibahas dalam tulisan ini. Metode sejarah kritis digunakan untuk mengungkap historical aspect dari peristiwa bencana alam dalam kaitannya dengan kebijakan dan masifnya penetrasi ekonomi global yang kapitalistik dan eksploitatif terhadap sumber daya alam. Sejalan dengan pemikiran C. Wright Mills, bahwa "Every social science or better, every well considered social study-requires an historical scope of conception and a full use of historical material' (Skocpol, 1984). 
Dalam konteks ini metode sejarah merupakan seperangkat aturan dan prinsip yang sistematis untuk mengumpulkan sumber-sumber penulisan secara efektif, menilainya secara kritis, dan menyajikan sintesa hasil-hasil yang dicapai dalam bentuk tertulis (Garraghan, 1957: 18). Dalam metode sejarah ada empat langkah yaitu, heuristik (pengumpulan data), kritik (intern dan ekstern), interpretasi (analisis dan sintesis), dan historiografi (Gottschalk, 1969: 32).

\section{GERAKAN SOSIAL LINGKUNGAN DALAM DINAMIKA SEJARAH}

Secara konseptual gerakan sosial lingkungan atau environmental social movement sesungguhnya merupakan trianggulasi gerakan sosial dan politik yang bertujuan untuk melestarikan dan memperbaiki lingkungan alam melalui pendidikan masyarakat (public education), advokasi terhadap pilihan-pilihan gaya hidup yang lebih baik, perbaikan dalam perencanaan komunitas (improved community planning), peningkatan investasi finansial, dan regulasi pemerintah (Jenkins, 1983). Gerakan lingkungan sesungguhnya mencakup dan meliputi berbagai organisasi yang berbeda dan kadang-kadang terpisah, mulai dari organisasi-organisasi yang kuat secara finansial pada tingkat nasional dan internasional hingga ribuan organisasi lingkungan yang bersifat volunter dan beroperasi pada tingkat grassroots dan bahkan juga mencakup individuindividu yang berjuang hanya pada tingkat lokal. Jadi dapat dikatakan, bahwa pada awalnya keprihatinan terhadap kelestarian lingkungan alam merupakan daya dorong utama yang melahirkan berbagai gerakan lingkungan.

Keprihatinan terhadap kelestarian alam dan kesadaran terhadap bahaya kerusakan alam yang mengancam kehidupan manusia dikemukakan pertama kali oleh Malthus pada abad XVIII. Kemudian Gidden yang mengatakan bahwa di antara bahaya-bahaya global yang dapat mengancam eksistensi manusia di bumi adalah adanya 'ecological calamity and uncontainable population explosion' (Yearley, 1997). Namun demikian, keprihatinan terhadap masa depan lingkungan hidup dan kelestarian kehidupan manusia belum menjadi sebuah gerakan kolektif yang menyandang ideologi tertentu. Baru setelah perempat ketiga abad XX gerakan lingkungan menjadi sebuah gerakan kolektif yang terorganisasi terutama ketika industrialisasi dan ekspansi kapitalisme sudah demikian berkembang dan menimbulkan dampak-dampak ekologis yang mengkawatirkan bagi kehidupan umat manusia.

Sebagai dampak industrialisasi dan mekanisasi alat transportasi, maka masalah awal yang ditangkap para aktivis lingkungan adalah persoalan polusi yang terjadi terutama pada tahun 1950-an, 1960-an dan 1970-an. Berbagai gerakan lingkungan muncul untuk menjaga udara dan air dari polusi. Untuk selanjutnya para aktivis lingkungan bukan hanya membatasi diri pada lingkungan, tetapi juga hal-hal lain yang bersifat unik seperti tumbuhan dan binatang liar yang unik, proteksi terhadap makluk langka. Gerakan ini cukup membawa hasil di AS misalnya dengan keluarnya berbagai peraturan Clean Water Act, Clean Air Act, Endangered Species Act, National Environmental Policy Act, dan sebagainya yang menjadi landasan bagi penciptaan lingkungan yang standar.

Oleh karena peningkatan kesadaran publik dan ekspansi dari ilmu-ilmu lingkungan pada beberapa tahun terakhir ini, maka isu-isu lingkungan juga mengalami perkembangan yang luar biasa bahkan telah berhasil mengembangkan konsep-konsep kunci mengenai masa depan kehidupan umat manusia di bumi seperti konsep 'sustainability' yang mengacu kepada bagaimana umat manusia dapat hidup berdampingan secara harmonis dengan alam secara berkelanjutan dengan prinsip simbiosis mutualisme (Castro, 2004). Di samping itu, perkembangan tersebut juga telah memunculkan kesadaran baru mengenai berbagai perubahan lingkungan yang sangat mengkhawatirkan umat manusia seperti penipisan lapisan ozon (ozone depletion), perubahan iklim (climate change), dan polusi biogenetik (biogenetic pollution) (Langhelle, 1999). 
Para aktivis gerakan lingkungan biasanya memiliki sistem-sistem nilai, pegangan moral, dan idola mengenai kepahlawanan yang relatif sama. Namun demikian seringkali mereka juga memiliki perbedaan terutama menyangkut soal-soal yang lebih detail seperti masalah prioritas dan tekanan gerakan mereka, cara-cara melakukan aksi, dan tujuan-tujuan khusus yang hendak mereka capai. Gerakan lingkungan, dalam bentuknya yang murni, cenderung untuk mewakili kepentingan publik secara luas yang menyangkut soal udara bersih, air bersih, makanan sehat, binatang, keindahan alam, ruang terbuka, dan sebagainya. Selain itu, gerakan lingkungan juga sangat konsen terhadap perlindungan terhadap binatang termasuk binatang liar dari upaya perburuan baik untuk hobi maupun untuk dikonsumsi.

Satu hal yang sangat menarik adalah bahwa berbagai gerakan dan organisasi lingkungan saling berinteraksi dan memiliki hubungan satu dengan yang lain dan bahkan memiliki link dengan berbagai jenis gerakan sosial yang lain yang memiliki pandangan moral yang sama. Oleh karena itu, tidak mengherankan jika gerakan lingkungan juga bekerja sama dengan gerakan sosial untuk perdamaian, perjuangan hak-hak manusia dan binatang, gerakan menentang penggunaan senjata nuklir, gerakan peduli penyakit endemik, kemiskinan, kelaparan, dan sebagainya. Oleh karena jaringan yang dimilikinya inilah, kebanyakan gerakan lingkungan memiliki dimensi global.

Meskipun gerakan dan organisasi lingkungan pada saat ini memiliki kecenderungan untuk menyebar ke berbagai wilayah negara bahkan provinsi atau pun unit wilayah yang lebih kecil dan bersifat lokal, atau sering disebut ecoregions, namun demikian mereka secara umum memiliki spirit yang sama dalam memperjuangkan kelestarian lingkungan hidup. Di samping itu, kerja sama di antara mereka baik secara nasional maupun secara internasional sangat solid sebagai sebuah jaringan, sehingga dari sisi organisasi adakala mencerminkan organisasi lintas-batas atau boundaries organization (Forsyth, 2003).
Sifat global dan 'lintas batas' dari organisasi dan gerakan lingkungan ini juga menimbulkan konsekuansi yang luar biasa bagi masyarakat lokal, di mana gerakan lingkungan itu beroperasi atau melakukan kegiatan. Dalam hal ini Forsyth (2003) mengemukakan bahwa organisasi-organisasi lingkungan sering kali menjadi tantangan yang potensial bagi jaringan kekuasaan yang dalam hal ini adalah pemerintah (tentu saja pemerintah yang 'tidak ramah lingkungan'). Menurut Prijono bahwa hubungan kerja gerakan lingkungan dengan pemerintah bersifat kontekstual dan berfluktuatif. Ada kalanya timbul pertentangan karena memiliki orientasi dan kepentingan yang berbeda. Namun demikian secara umum pola hubungan itu dapat dibagi menjadi tiga yaitu asosiatif, paralel, dan konfliktif. Terdapat beberapa variasi dalam hubungan antara gerakan lingkungan dengan pemerintah yaitu sangat dekat, sejajar, dan mengambil jarak (Prijono, 1995).

Bidang perhatian mereka terhadap kelestarian lingkungan dan jaringan mereka yang bersifat global memberikan kesan sebagai organisasi dan gerakan yang netral dari pengaruh konflik politik global, meskipun sering kali aktivitas mereka bertabrakan dengan berbagai kekuatan politik baik nasional maupun internasional. Hal ini bisa dicontohkan dari sepakterjang yang dilakukan oleh berbagai gerakan lingkungan seperti Greenpeace, Green Parties, dan grup seperti ACTtivist Magazine yang memiliki kepedulian di bidang ekologi, biodiversity dan sebagainya yang diarahkan untuk pelestarian lingkungan dan perdamaian. Mereka beroperasi pada tingkat lokal, namun bila perlu mereka juga terlibat dalam berbagai persoalan ancaman lingkungan pada tingkat global. Kelompok seperti Bioregional Revolution diharapkan mampu menjembatani berbagai perbedaan kepentingan antara industri yang mengeksploitasi sumber daya alam dengan berbagai kelompok yang menghendaki pelestarian alam. Masalah seperti ini akan menjadi salah satu problem utama pada abad XXI ini. 


\section{KAPITALISME DAN PERUSAKAN LINGKUNGAN}

Kerusakan lingkungan terutama yang terjadi di negara-ngara berkembang seperti Indonesia menimbulkan banyak kontroversi. Banyak pakar yang melihat bahwa kerusakan lingkungan di Negara-negara berkembang ini disebabkan oleh ekspansi kapitalisme yang terwujud kolonialisme (penjajahan) melalui proses imperialisme yang berlangsung sejak abad XV. Nafsu kapitalisme yang menginginkan penumpukan kapital yang sebesar-besarnya secara tidak terbatas sehingga mendorong sumber daya alam (lewat eksploitasi) dan sumber daya manusia (lewat perbudakan) serta sumber daya sosial-budaya (lewat penjajahan) dipacu sedemikian rupa supaya mampu memenuhi nafsu produksi kapitalis. Akhirnya negeri jajahan pun dieksploitasi melebihi apa yang dapat dicapai secara normal. Fenomena ini telah menyebabkan perusakan lingkungan sebab potensinya dikeruk melebihi kapasitasnya (Dharmawan, 2005).

Contoh menarik dari kasus eksploitasi kolonial yang berlebihan (over exploitation) dalam kaitannya dengan bencana sosial dan lingkungan terjadi di Jawa. Seperti diketahui bahwa sejak 1830 pemerintah kolonial Belanda menerapkan program eksploitasi kapitalis di bidang pertanian dengan nama Cultuurstelsel (cultivation system) atau Tanam Paksa. Banyak kajian mengenai sejarah Tanam Paksa, namun suatu kajian mengenai dampak sistem eksploitasi ini terhadap perusakan lingkungan masih belum memadai. Meskipun agak kontroversial, Clifford Geertz merupakan pakar antropologi yang membuat analisis mengenai kaitan antara faktor kebijakan politik kolonial yang bersifat kapitalistik, dengan kondisi sosial budaya masyarakat pribumi, dan beban ekologis yang sangat berat. Geertz melukiskan suatu kombinasi yang asing ekstensifikasi perkebunan kapitalis, intensifikasi pertanian pribumi, dan stagnasi yang berakar pada sistem Tanam Paksa. Ia mengajukan konsep 'involusi pertanian' yang mengacu kepada kemandegan atau kemacetan pola pertanian yang ditunjukkan oleh tidak adanya kemajuan yang hakiki. Dalam kondisi yang seperti inilah bencana ekologi yang sangat kecil sekalipun akan menimbulkan bencana sosial yang yang dahsyat seperti bencana kelaparan dan wabah kematian di pulau ini (di Demak, Semarang, Cirebon) pada pertengahan abad XIX (Geertz, 1976). Praktik ekonomi kapitalis inilah yang melahirkan kerusakan ekologi di negara-negara jajahan seperti yang terjadi Indonesia.

Ketidakmampuan para penguasa negerinegeri bekas jajahan untuk melepaskan diri dari sistem kapitalisme setelah mereka mencapai kemerdekaan sangat mudah dipahami. Hal ini berkaitan dengan fakta bahwa kolonialisme telah mengembangkan hubungan produksi kapitalis model ketat (tight capitalist relation of production) (Dharmawan, 2005). Pada pascakolonial terutama sejak Orde Baru, Indonesia cenderung melanjutkan sistem ekonomi kapitalis atau berada dalam subordinasi struktur negara kapitalis, maka kerusakan ekologi menjadi bertambah semakin parah. Kehancuran ekologis terus berlanjut melalui program pembangunan yang sejatinya adalah metamorphose belaka dari hubungan produksi kapitalisme. Negeri bekas jajahan tetap diposisikan sebagai pasar dan pemasok cheap labor and raw materials. Negara bekas penjajah tetap menjadi pusat (center), sedangkan negeri-negeri bekas jajahan tetap berposisi sebagai negeri pinggiran (periphery). Ketergantungan (dependency) tetap berlangsung terus. Globalisasi dan berbagai isu strategis seperti Hak Asasi Manusia (HAM) dan lingkungan dijadikan sebagai alat pelanggeng bagi negerinegeri bekas penjajah untuk menjadi penjajah model baru (neo- kolonialisme), mengeksploitasi negeri bekas jajahan. Melalui funding agency seperti International Monetary Fund (IMF), negeri-negeri bekas penjajah memaksakan model pembangunan kapitalistik untuk melanggengkan ketergantungan tersebut. Dengan demikian yang terjadi adalah bukanlah sustained growth (pembagunan berkelanjutan) bagi negeri-negeri bekas jajahan tetapi yang terjadi adalah 
kehancuran ekologi yang berkelanjutan (sustained ecological devastation).

Sementara itu fenomena-fenomena yang secara langsung mengancam kelestarian lingkungan berjalan terus. Privatisasi dan komersialisasi sumber-sumber kehidupan tengah berlangsung saat ini, mulai sektor air, hutan, benih tanaman pangan, tambang migas dan mineral lainnya, pesisir kelautan, dan lain-lain. Privatisasi, atau tepatnya komersialisasi, eksplotasi sumber daya lingkungan ini jelas akan menjadi ancaman bagi kelestarian lingkungan. Ekologi akan dieksploitasi secara optimal dengan harapan dapat mendatangkan keuntungan ekonomis yang sebesar-besarnya. Perhitungan ekonomis dan keuntungan (profit oriented) inilah yang menjadi biang keladi terhadap kehancuran lingkungan. Padahal sumber daya lingkungan itu bukan merupakan warisan nenek moyang, tetapi merupakan pinjaman dari generasi mendatang. Kenyataan ini sudah memperlihatkan siapa sebenarnya yang diuntungkan dari cara eksploitasi lingkungan ini; pemodal-kapitalisme, siapa yang dimiskinkan; rakyat tertindas dan siapa yang harus menerima dampak lingkungan yang rusak; lingkungan itu sendiri dan manusia di sekitarnya yang membutuhkan.

\section{CIVL SOCIETY DALAM KONTEKS GLOBAL ENVIRONMENTAL GOVERNANCE}

Gerakan lingkungan merupakan wujud dan/atau bagian dari apa yang dikonsepkan sebagai civil society dan sebaliknya gerakan lingkungan juga memiliki kontribusi yang signifikan dalam proses penguatan civil society. Letak kekuatan gerakan lingkungan dalam menyokong penguatan civil society berada pada kenyataan bahwa gerakan lingkungan memiliki jaringan international tanpa banyak menghadapi kendala batas-batas negara.

Pada saat ini wacana civil society masih menjadi perbincangan dan perdebatan ilmiah yang begitu hangat di Indonesia. Polemik ini berkisar pada hubungan antara civil society dan negara. Inti persoalannya menyangkut pada perdebatan seberapa besar peran negara dan sebaliknya juga peran masyarakat dalam menentukan kebijakan yang menyangkut kepentingan publik. Apakah civil society berperan sebagai penyeimbang, pesaing, atau penentang kekuatan dan kekuasaan negara? Pendek kata 'negara' telah dicurigai sebagai perampas hak-hak civil society sehingga posisi dan peran civil society menjadi lemah. Namun demikian, perdebatan itu sedikit melupakan kenyataan historis dan sekaligus aktual bahwa sesungguhnya kekuatan kapitalisme global sebagai kekuatan raksasa merupakan tantangan yang tidak kalah dahsyat dalam proses penguatan civil society di masa depan. Kenyataan ini sering dilupakan karena kapitalisme global yang sebetulnya merupakan produk dari liberalisme akan memberikan kebebasan kepada setiap elemen masyarakat untuk mengaktualisasikan diri dan menjunjung hak asasi manusia. Namun demikian, hal yang terlupakan adalah bahwa justru dalam kebebasan itulah kekuatan raksasa akan cenderung 'memaksakan' kepentingannya dengan berbagai cara.

Harus diakui bahwa kajian civil society muncul dan makin marak seiring dengan euphoria semangat kebebasan menyusul jatuhnya rezim Orde Baru. Pencarian genealogi konsep civil society ini melahirkan dua pendapat yang berbeda mengenai konsep civil society. Pendapat pertama menerjemahkan civil society dengan 'masyarakat madani', sedangkan pendapat kedua menerjemahkan konsep ini dengan terjemahan secara literer yaitu 'masyarakat sipil' (Baso, 1999).

Pendapat pertama menerjemahkan civil society dengan 'masyarakat madani' dalam pengertian masyarakat yang bersifat komplemen atau suplemen terhadap negara. Pemaknaan ini terutama dirujukkan pada konsep dan formulasi masyarakat Madinah yang dibangun oleh Nabi Muhammad SAW, yang digambarkan sebagai prototype ideal masyarakat demokratis, egaliter, adil, dan berkeadaban. Piagam Madinah dianggap sebagai konstitusi awal yang mendahului Declaration of Human Rights PBB tahun 1948. Singkatnya, pada zaman itulah civil society, dalam pandangan kelompok ini, memperoleh pembenarannya, legitimasi historisnya dalam masyarakat 
Muslim. Namun demikian persoalannya adalah apakah prototype masyarakat Madinah ketika itu dapat dijadikan prototype masyarakat moderen yang sangat kompleks seperti sekarang ini?

Kelompok yang menerjemahkan civil society sebagai 'masyarakat sipil' beranggapan hal ini memiliki relevansi erat dengan perjuangan demokratisasi di Indonesia. Dengan mempertahankan karakter civil society dalam konteks budaya Barat, yaitu sebagai counterbalancing terhadap negara, masyarakat sipil memerankan dirinya sebagai alat kontrol negara, bahkan perlawanan bagi kecenderungan otoritarianisme baru negara dalam proses transisi. Dalam konteks ini yang terpenting adalah kontekstualisasi gagasan itu dalam upaya penguatan potensi masyarakat dalam kehidupan bersama. Masyarakat sipil diperhadapkan dengan negara karena negara dianggap bukanlah institusi 'baik hati' yang aktor-aktornya dengan tanpa pamrih memperjuangkan kepentingan rakyat. Jadi, diperlukan masyarakat sipil yang kuat dan mapan sebagai alat penekan dan kontrol terhadap seluruh kebijakan negara, kalau perlu berseberangan dengan negara.

Namun demikian, memandang negara sebagai satu-satunya obstacle dalam penguatan civil society merupakan gejala 'rabun senja' yang perlu diwaspadai mengingat bahwa dalam era kapitalisme global ini peran negara sedang dikebiri oleh kekuatan kapitalisme global. Paham neoliberalisme yang disokong oleh kekuatan kapitalisme global mengindoktrinasikan bahwa peran negara harus dikurangi dan digantikan oleh kekuatan sektor swasta yang tentu saja merupakan domain kapitalisme global. Dalam konteks ini rezim pasar yang dikendalikan oleh kekuatan modal transnational corporations (TNCs) lah yang sebetulnya berkuasa. Dengan isu-isu yang dilontarkan, mereka telah mampu menghilangkan batas-batas negara. Ideologi neoliberal menolak intervensi negara dan mengharamkan proteksionisme negara, demi perdagangan bebas yang akan menggerakkan persaingan dan mengembangkan pemanfaatan sumber-sumber daya, tenaga kerja, dan modal secara efisien.
Dengan pandangan yang seperti inilah sebetulnya posisi negara akan tersubordinasi oleh kapitalisme global dan kekuatan modal dan dengan demikian kekuasaan negara sebetulnya juga menjadi semu belaka.

Hadirnya kepentingan rezim kapitalisme global dalam negara pada akhirnya memaksa civil society untuk menghadapi dua kekuatan sekaligus yaitu kekuasaan negara dan kekuatan kapitalisme global. Tantangan yang berasal dari negara berupa kebijakan dan tindakan yang represif terhadap gerakan sosial, sedangkan tantangan yang berasal dari kapitalisme global mengejawantahkan diri ke dalam kekuatan pasar yang dikendalikan oleh struktur kapitalisme global. Sementara itu, juga terdapat pergulatan antara negara dan kekuatan kapitalisme global. Di satu pihak kapitalis global ingin memanfaatkan negara sebagai agen untuk mengeksploitasi di walayahnya, sementara itu negara juga ingin memanfaatkan kaum kapitalis untuk mendorong laju perekonomian negaranya.

Di dalam pola gerakan lingkungan pun sudah sewajarnya untuk menghitung kekuatan neoliberalisme atau gobalisasi kapitalis dan apa yang akan dibutuhkan sebagai varian polarisasi gerakan lingkungan sebagai salah satu gerakan sosial untuk melawannya. Ini pun berkorelasi dengan kekuatan negara sebagai fasilitator kekuatan globalisasi kapitalis dalam eksploitasi sumber daya alam. Sebagai contohnya, pada masa Orde Baru, negara melalui birokrasi dengan dukungan instrumen kekuatan militernya sukses mengamankan atau memperlancar proses eksploitasi sumber daya alam dan akumulasi kapital.

Dalam konteks di atas itulah sesungguhnya gerakan lingkungan yang memiliki kepedulian terhadap pelestarian lingkungan sebagai aset yang memenuhi 'hajat hidup orang banyak' dari tindakan destruktif yang dilakukan baik oleh negara maupun oleh korporasi global atau kerja sama antara keduanya, akan menyadarkan dan mendorong masyarakat lokal untuk ikut berjuang melestarikan ekologi sebagai bagian dari Global Environmental Governance. Gerakan lingkungan akan dapat memperkuat posisi tawar-menawar 
civil society dalam memperjuangkan hak-hak mereka dalam kaitannya dengan lingkungan. Mereka memiliki kekuatan itu karena mereka memiliki jejaring yang bersifat global, sehingga para kapitalis dan negara harus berhitung untuk melakukan tindakan represif terhadap mereka. Dengan demikian berkembangnya gerakan lingkungan akan memperkuat posisi civil society dalam membangun tata lingkungan global yang berkesinambungan demi kesejahteraan manusia.

\section{SIMPULAN}

Dari dinamika sejarah gerakan sosial lingkungan di Indonesia, secara umum terbukti dapat mendukung proses penguatan civil society yang pada gilirannya secara bersama-sama dapat berjuang untuk menegakkan tata lingkungan global yang sustainable demi kesejahteraan masyarakat. Dengan melihat beban yang berat dari gerakan lingkungan dalam menghadapi kekuatan yang dapat merusak lingkungan (baik dari kebijakan negara maupun dari ekspansi kapitalisme global atau kolaborasi dari keduanya), maka berbagai langkah harus ditempuh. Sudah barang tentu langkah-langkah itu bukan terwujud dalam gerakan moral, tetapi harus melakukan action. Dalam konteks ini perjuangan untuk melestarikan lingkungan bukan hanya bersifat defensif yang hanya 'bergerak' ketika lingkungan alam sudah mulai dirusak, tetapi juga harus bersifat ofensif untuk mengoreksi segala macam kebijakan negara yang diproyeksikan akan memiliki dampak terhadap kerusakan alam seperti; penjualan konsesi penebangan hutan yang tidak terkontrol termasuk penambangan di daerah hutan lindung; mencabut peraturan yang mengingkari kedaulatan rakyat untuk mendapatkan akses terhadap pemanfaatan lingkungan hidup secara wajar dan berkesinambungan. Selain itu, aparat keamanan betul-betul dipersiapkan untuk menangani dan mencegah tindakan brutal terhadap lingkungan seperti adanya illegal logging.

Secara institusional berbagai gerakan lingkungan di Indonesia perlu menekankan perlunya satu institusi payung yang mengurusi lingkungan hidup. Tidak seperti sekarang yang terlalu banyak institusi seperti Menteri Lingkungan Hidup-non Departermen, Menteri Kehutanan, Menteri Pertambangan Sumber Daya Energi dan Mineral, Menteri Pertanian, Menteri pemukiman dan Prasarana wilayah, dan lain-lain. Mereka memiliki pola koordinasi sendiri-sendiri sehingga sangat lamban dalam menangani persoalan lingkungan yang sering kali membutuhkan penanganan yang mendesak. Selain itu, adalah tugas perjuangan dari gerakan lingkungan untuk mewujudkan perlindungan terhadap hak setiap warga negara atas hak untuk mendapatkan lingkungan yang bersih dan sehat serta mempunyai hak pengelolaan sumber daya alam dan sumber-sumber kehidupan, secara adil dan merata dengan mengedepankan keberlanjutan ekologis (sustainable ecologis). Dengan cara demikian maka gerakan lingkungan akan memperkuat civil society dalam menegakkan tata lingkungan dunia yang berkelanjutan (sustained global environmental governance).

\section{REFERENSI}

Baso, Ahmad (1999). Civil Society Versus Masyarakat Madani. Jakarta: Pustaka Hidayah.

Castro, C. J. (2004). Sustainable Development: Mainstream and Critical Perspectives. Sage Publication.

Dharmawan, Arya Hadi (2005). Gerakan Sosial Lingkungan dan Perubahan Titik Berat Kekuatan Politik Sipil Era Demokrasi. Bogor: Suplemen Matakuliah Ekologi Politik Pedesaan S3 pada Program Studi Sosiologi Pedesaan Sekolah Pascasarjana IPB.

Dwivedi, Ranjit (2001). Environmental Movements in the Global South. London, Thousand Oaks: Sage Public.

Escobar, Arturo (1997). "Cultural Politics and Biological Diversity: State, Capital and Social Movements in the Pacific Coast of Colombia.” In R. Fox and O. Starn (Eds). 
Between Resistance and Revolution. New Brunswick: Rutgers University Press.

Forsyth, Tim (2003). Critical Political Ecology: The Politics of Environmental Science". London: Routlegde.

Garraghan, Gilbert J., S. J. (1957). A Guide to Historical Method. New York: Fordham University Press.

Geertz, Clifford (1976). Involusi Pertanian. Jakarta: Bhratara Karya Aksara.

Gottschalk, L. (1969). Mengerti Sejarah. Terjemahan Nugroho Notosusanto. Jakarta: UI Press.

Hadi, Sudharto P. (2006). "Mengurai Bencana Banjarnegara”, Suara Merdeka 11 Januari 2006.

Jenkins, J. Craig (1983). Resource Mobilization Theory and the Study of Social Movements. Annual Review of Sociology, 5: 527-553, https://doi.org/10.1146/ annurev.so.09.080183.002523.

Langhelle, Oluf (1999). Sustainable Development: Exploring the Ethics of Our Common Future. International Political Science Review, 20 (2): 129-149.

Pingali, Prabhu L. (1989). Institutional and Environmental Constraints to Agricultural Intensification. Population and Development Review, 15: 243-260.

Prijono, Onny S. (1995). Peran Organisasi Nirlaba, Lembaga Pengembangan Swadaya Masyarakat dan Lembaga Swadaya Masyarakat serta Pola Interaksi dengan Pemerintah' dalam Bantarto Bandono, dkk. Refleksi Setengah Abad Kemerdekaan Indonesiai. Jakarta: CSIS.

Robinson, Nicholas A. (1984). Rehabilitating Historic Properties: Practicing Preservation Law. New York: Practicing Law Institute.

Sajogyo (1974). Modernization Without Development in Rural Java. Bogor: Makalah tidak diterbitkan.

Skocpol, T. (1984). Vision and Method in Historical Sociology. London: Cambridge University Press.
Yearley, Steven (1997). 'Social Movements and Environmental Change', dalam Michael Redclift \& Ted Benton eds. Social Theory and The Global Environment. London \& New York: Roudledge.

"BNPB: Kurun 10 Tahun, Longsor Tewaskan 1.815 Orang", http://www.liputan6.com, 15 Desember 2014. 